\title{
Green Accounting Model Using Maqasid Al-Syariah Contemporary Concept Approach
}

\author{
Tantina Haryati ${ }^{1}$,Muslich Anshori ${ }^{2}$, Basuki $^{3}$ \\ \{tantinacounting@gmail.com $\left.{ }^{1}\right\}$ \\ ${ }^{1}$ UPN Veteran Jatim, Indonesia \\ ${ }^{2,3}$ Universitas Airlangga, Indonesia
}

\begin{abstract}
Green accounting practices in Indonesia have not been effective so far. The level of rapid development growth in each region coupled with the existence of autonomy sometimes overrides environmental aspects that are realized or not will ultimately be the main cause of environmental problems. The form of the company's implementation of environmental accounting in the form of CSR, in higher education is known as USR. With the Islamic USR concept approach that is with the concept of contemporary maqasid syariah, namely hifdz al-huquq al-Insan (protection of human rights) and embodiment of social solidarity. This research uses a case study research approach through a qualitative approach. The object of this research is green accounting in USR based on classical and contemporary sharia maqasids. The subject of this research is an Islamic-based university that applies Green accounting, the University of Muhammadiyah Malang. The results of the study show that the first: Green accounting indicators namely environmental awareness, environmental involvement, environmental reporting and environmental audits of USR based on contemporary sharia maqasids show the awareness of academicians to safeguard the environment by increasing resource efficiency by reducing pollution or damaging activities. Campus environment by conducting good environmental management and there is good and responsible financing management for the campus environment program so that the university's image becomes good in the community. Second: the green accounting model with a contemporary Islamic maqasid approach is the hifdz al-huquq al-Insan approach (protection of human rights) and embodiment of social solidarity at UMM paying attention to the surrounding environment which is marked by the involvement of the academic community in terms of environmental preservation, one way is by utilizing technology to simplify the implementation of activities.
\end{abstract}

Keywords: green accounting, maqasid syariah, university social responsibility..

\section{Introduction}

Green accounting based on Corporate Social Responsibility (CSR) has been widely implemented by large companies as a form of corporate responsibility for the environmental impact on their business. While the form of social responsibility in higher education is called the University Social Responsibility (USR) which is basically an ethical policy that affects the quality of the performance of the college community which includes students, managers, teachers, and all college employees through management responsibility for the impact of education, cognitive , employment, and the environment produced by universities through an interactive dialogue with the community in order to produce sustainable human development. 
(Astiti, 2014). This study incorporates the context of the Islamic perspective of business practices that have ethical ethical responsibilities in Islam. Companies or institutions incorporate Islamic religious norms that are marked by a commitment to sincerity in maintaining social contracts in its operations. This is not only in environmental issues but Islam also offers certain predictions relating to humans, their civilization and the future. Islam attaches great importance to the preservation and protection of the quality of the natural environment. The environmental problem is indeed a global issue because it involves various sectors and various interests of mankind. The emergence of damage to nature or the environment is largely the result of human actions, because it is man who is given the responsibility as a caliph on earth (Rodin, 2017). In His Word Allah SWT calls it:

\section{Q.S. Ar-Rum ayat 41-42}

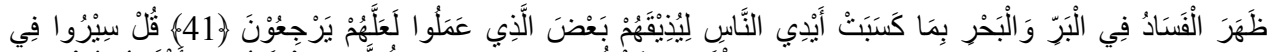

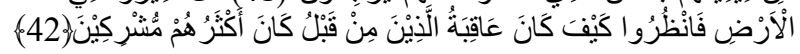

41. It has been seen that in the land and in the sea it is caused by the works of men, that Allah may feel for them some of the consequences of their actions, that they may return (to the right path).

42. Say "Take a journey on the earth and see how the last of the people will be. Most of them are allies (Allah)."

\section{Q.S.Al-A'raf ayat 56-58}

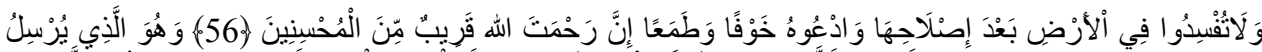

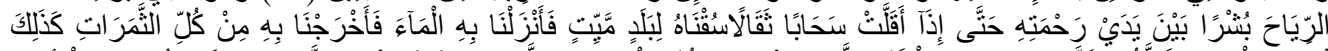

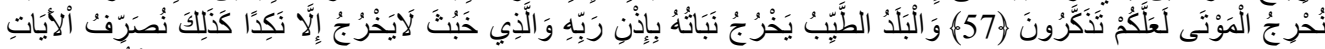

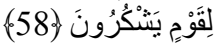

56. And do not make mischief on earth, after (God) has repaired it and pray to Him with fear (will not be accepted) and hope (will be granted). Indeed, God's grace is very close to those who do good. 57. And it is he who blows the wind as the bearer of joyous news before the arrival of His mercy (rain); so that when the wind has brought a cloudy wind, we turn to a barren area, then we send rain in that area, then we remove it because the rain is a variety of fruits. That's how we raise people who have died, hopefully you take lessons. 58. And good soil, its plants flourish with the permission of Allah; and infertile soil, the plants only grow miserable. Thus we repeat (our) signs of greatness for those who are grateful.

Environmental preservation is also mentioned in the Muslim HR hadith in its hadith from Jabir ra,

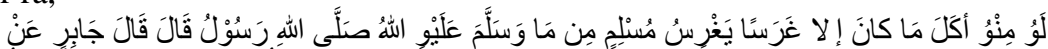

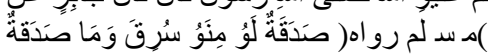

Meaning: From Jabir ra, He said Rosulullah SAW, "There is no Muslim who plants plants, but the results of planting, but the yield of plants that are eaten will be alms for him, and the results of stolen plants will become alms." 
From this hadith states that by practicing religious teachings, we will be able to preserve the environment and organize as neatly as possible by creating security, order and beauty on our beloved earth by realizing "cleanliness is part of faith".

The concept of environmental preservation which is reflected in the management of green accounting in Higher Education strongly supports the concept of green economy, namely human welfare, environmental sustainability, and ecosystems as evidenced by pro-growth, pro-poor, and pro-job and pro-environment jargon. Management of green accounting in accordance with the objectives, basic principles and systems in Islamic economics, namely to prosper humanity in the direction of improving the quality of human life and nature where by looking at the Islamic perspective that is through contemporary sharia maqasid developed by Jasser Auda namely from the level of Hifdz al-huquq al- Insan (protection of human rights) and the embodiment of social solidarity from the 6 levels described by Jasser Auda namely Hifdz al-Hurriyyah al-I'tiqad (protection of freedom of belief), Hifdz al-huquq al-Insan (protection of human rights), the embodiment of social solidarity, the embodiment of scientific thinking or the embodiment of the spirit of seeking knowledge, Hifz al-usrah (family protection) and the protection of human dignity / human rights / human rights. With the contemporary Islamic maqasid approach, Auda is oriented to become maqasids that are more universal, more social and humanitarian in nature (human rights and freedoms). Whereas the classical maqasid is more of a preventive effort, then the contemporary maqasid of Jasser Auda is more of a development and protection provision for human rights, and this is in accordance with the needs and problems experienced by Muslims today and prioritizes the social aspects of society.

Islam has a principle of equal accountability in all its forms and scope, between body and soul, between individuals and families, between individuals and social, and between a society and other societies. Social responsibility refers to the obligations of a company to protect and contribute to the community where the company is located. In the perspective of Islamic CSR (called ICSR) in this case the University Social Responsibility (USR) is the realization of the concept of the Ihsan teachings as the culmination of very noble ethical teachings (Wahyuddin, 2016). Ihsan is carrying out good deeds that can provide opportunities for benefit to others in order to get the blessing of Allah SWT. The concept of the Ihsan teachings is interpreted through the hadith Gabriel of Umar bin Khattab r.a, the hadith reads: "Ihsan is that you worship God as if you saw Him, if you see Him, then surely Allah sees you" (HR. Bukhari). Based on the hadith Ihsan is one of the important and strategic pillars of religion in order to realize a quality Muslim figure. Because if a person always does Ihsan, then he will carry out the good in an optimal way, both in quality and in quality and always try to do good deeds simultaneously for the sake of self-perfection.

CSR is the implication of the teachings of ownership in Islam. Allah SWT is the owner of mutlaq (haqiqiyah) while humans are only limited as temporary (temporary) owners who function as recipients of the mandate. CSR is in line with the Islamic view of humans in relation to themselves and the social environment, which can be presented with four axioms namely unity (monotheism), balance (equilibrium), free will (freewill) and responsibility (responsibility). Implementation of CSR in Islam in detail must meet several elements that make it spirit so that it can distinguish CSR in an Islamic perspective with CSR universally namely Al-Adl, Al-Ihsan, Benefits and Trust (Djakfar, 2007).

In Yousef's research (2003) that an organization can be categorized as taking part in protecting the environment if it has environmental awareness followed by the organization's involvement with environmental issues with environmental reporting, especially organizational performance. in overcoming the impact of organizational activities on the 
environment, which is then enhanced by environmental auditing to measure and evaluate organizational performance.

The success of achieving a campus based on good and ideal environmental management is certainly not only marked by physical achievement alone. However, there are also nonphysical things that need attention together. This can be understood from the willingness to change attitudes and mindset of all elements of higher education in the surrounding environment. Therefore, the cultural movement for environmental love can certainly be part of the lifelong education process. Because, the campus is a strategic place in transferring values as well as transferring knowledge based on experience and practice in everyday life. This is where the central position and role of the campus in unraveling environmental problems is always awaited for the future of the motherland.

The attention of an organization in the environment is very important in organizational sustainability, therefore the movement for environmental love culture is also applied in various Private Universities in Indonesia. One of them is the University of Muhammadiyah Malang (UMM), where researchers chose the University based on the research theme of the Islamic paradigm: Islamic Maqasid, which is to conduct studies to describe the implementation of Green Accounting in Islamic Maqasid-based Social Responsibility University based on the vision of UMM namely "In 2030 to become a leading University in the development of science, technology and art (IPTEKS) based on Islamic values, and based on UMM's mission, namely: 1) Organizing education and learning in a professional manner based on research and development of Science and Technology, 2) Organizing research that contributes to the development of Science and Technology), 3) Organizing research-based community service to improve community welfare, 4) Collaborating with other parties that are mutually beneficial, 5) Organizing development and development of the academic community based on values Islamic values and kemuhammadiyahan, and 6) Organizing university institutional management professionally based on Islamic values. This was also supported by the statement of the UMM Rector on April 23, 2016 that "UMM became one of the various reference campuses of the environment as an environmentally friendly campus that should be emulated by its environmental-related programs. The movement as an environmentally friendly campus with the jargon of 'UMM Green, Clean and Comfortabel' was launched in 2013. Therefore, all academicians in UMM must commit to contribute significantly to environmental preservation, "said UMM Rector, Fauzan on the sidelines of Commemoration Day. Earth."

UMM's real contribution to environmental management was the achievement of the ASEAN Energy Awards in the ASEAN Renewable Energy Project Management Competition in 2008 through the PLTMH (Micro Hydro Power Plant) program which came from the assistance of the Indonesian Ministry of Energy and Mineral Resources (ESDM). Alternative energy is able to sustain electricity consumption by more than $20 \%$. UMM also prepared PLTMH two units which operated at the end of 2014. UMM as a private university in Indonesia, especially as a University based on Islam is quite popular, which won the ranking of 7 best private universities and the awarding of AKU Kartika Kopertis VII East Java as the leading campus in East Java.

Therefore, in this study the researchers wanted to find out how the green accounting implementation model in USR is based on the contemporary Islamic maqasid for Higher Education. So the contribution of this research is the first to discuss how the green accounting model is implemented by universities using the concept of contemporary sharia maqasid Jasser Auda namely Hifdz al-huquq al-Insan (Protection of human rights) and the realization of social solidarity. 


\section{Research Method}

This research uses a qualitative approach with a case study method, referring to John W. Creswell in his book Research Design: Qualitative, Quantitative and Mixed Method Research that case studies an exploration of a bound system or a case / various cases from time to time through collection in-depth data that involves rich sources of information in a context. This bound system is bound by time and place while the case can be assessed from a program, event, activity or an individual and organization.

\subsection{Rationality of Selection of Research Types}

This research approach is a case study research through a qualitative approach. The data collected is not in the form of numbers, but the data comes from interview scripts, field notes, personal documents, memo notes, and other official documents. So that the purpose of this qualitative research is to describe the empirical reality behind the phenomenon in depth, in detail and thoroughly. Therefore the use of a qualitative approach in this study is to match empirical reality with the prevailing theory by using an exploratory approach which is research that seeks to explore / explore / arrange the phenomena under study in order to answer the problems that have been formulated. (Basuki, 2016). The research approach used by researchers in this study is an inductive approach, which is an approach by taking a general conclusion from the real facts in the field.

\subsection{Research Objects and Subjects}

The object of this research is the Green Accounting Model in the contemporary Maqasid Syariah concept approach. The subject of this research is an Islamic-based university that applies Green Accounting, the University of Muhammadiyah Malang.

\subsection{Types of Data and Data Collection Techniques}

\subsubsection{Types of Data}

The type of data used is qualitative data.

\subsubsection{Data Collection Techniques}

Data collection is done by researchers by interacting directly with the object (getting-in), researchers must enter and "stay" in the location for a certain time (getting-along), conducting in-depth interviews, observing, and collecting documents related with the topic examined. Basuki (2016).

\subsubsection{Informant Selection Techniques}

According to Basuki (2016) the researcher must determine who will be chosen as the resource person / informant, and provide justification as to why he was chosen, determine how many sources to be selected, and when and how long the interview will take place. The selection of informants starts from key informants, and then progresses to several informants 
who are considered to know the problem being investigated. The selection of informants can use purposive sampling based on certain criteria according to their needs and uses, while the number of informants to be interviewed can be used snowball sampling techniques, namely the selection of informants starting from one person as a key informant then increased to as many informants as needed. Informants in this study are the head of the financial bureau, the Head of Accounting, Tax Office and Financial Reporting, the head of the general bureau, the Head of the Legal Bureau, the Head of the BPI (Internal Supervisory Agency) and PLSK.

\subsubsection{Data Analysis Techniques}

According to Basuki (2016) the data analysis stage is the most difficult stage in nonmainstream research. Researchers must be able to convince readers about the results of their research. In research using case studies have very casuistic criteria, so that research results can be "accepted or not" highly dependent on the arguments and logic built by researchers. This argument will be supported by the test "validity" of data and the reliability of "tools" conducted by researchers by triangulation (triangulation). In this study researchers used a data triangulation model (data triangulation).

The analysis technique used is an interactive model data analysis technique according to Mile \& Huberman (Sugiyono, 2010) which consists of four stages that must be carried out.

The stages are as follows:

1. Data collection,

2. Data reduction activities,

3. Presentation of data (data display), error.

4. Drawing conclusions and or verification stages.

\section{Result and Discussion}

\subsection{Research Results}

Green accounting practices in an organization consist of Environmental awareness, Environmental involvement, Environmental reporting and Environmental auditing and applied to universities in the form of social responsibility to the community, namely USR based on sharia maqasid, namely from the level of Hifdz al-huquq al-Insan (protection of human rights ) and the embodiment of social solidarity.

\subsubsection{Environmental Awarenes}

Researchers conducted interviews, conducted observations and took documentation to find out green accounting practices at UMM by conducting interviews with the head of the financial bureau, Head of Accounting, Tax Office and Financial Reporting, Head of general bureau, Head of Legal Bureau, Head of BPI (Internal Supervisory Agency) and PLSK. Researchers conducted interviews with the head of the UMM financial bureau about how environmental care at UMM was based on the approach of protecting human rights and the realization of social solidarity, the informant stated that:"UMM views the environment as something that must be nurtured and cared for according to Al-Baqarah's letter, namely that humans play a role as caliph. One form of UMM's concern for the environment is the 2014 chancellor's regulation on smoking bans in the campus area. Provision of bicycle ontel to support campus activities to reduce air pollution. And the separation of organic and nonorganic waste in the campus area. Since 2010 UMM has also been cooperating with the ministry of resources and energy in the form of micro-hydro technology where UMM supplies 
electricity by as much as $20 \%$, and UMM has also cooperated with the ministry of environment for land management for reforestation in areas outside the campus. "

The second participant was with the Tax and Financial Reporting Office stating that: "UMM cooperates with the second party with regard to environmental care through green campus activities with the bank BNI, with the aim of reducing things that degrade the quality of the environment on campus. UMM also established the BP2K institution, the unit responsible for building construction in the UMM region by reviewing the Amdal and topography of the region. "

The third participant was the Head of the General Bureau who stated that: "UMM cares about around in accordance with the guidelines and statutes and vision and mission to become a superior campus based on Islamic values in its last sentence, namely the development of science and technology based on Islamic values and to Muhamadiyahan, so in the context environmental maintenance, the support of UMM is in the form of maintaining infrastructure, maintenance and renovation, each of which has different tasks.

The fourth participant was the Chairperson of PLSK UMM who stated that: "the form of UMM activities that cares about the environment is a clean-up activity for the Brantas River, which is participated by employees, lecturers, students and the community in Batu."

From the four participants it could be concluded that UMM in its activities carried out environmental awareness. By referring to Islamic values and nobility, UMM has managed to manage the environmental atmosphere by reducing or reducing environmental pollution and saving existing natural resources, maintaining, maintaining and renovating infrastructure that supports the environment. UMM also provides renewable energy sources and solar cells to save electricity resources used for daily activities. This reflects that UMM implements contemporary sharia maqasid at the level of Hifdz al-huquq al-Insan (protection of human rights) and the realization of social solidarity in the academic community and surrounding communities.

\subsubsection{Environment Involvement}

Researchers conducted interviews, conducted observations and took documentation to find out how UMM was involved in the environment. Where the environmental involvement in UMM was reflected in several activities for this purpose, the researcher interviewed the first participant, the Head of Financial Bito who stated that: "UMM prepared a special budget for the environment posted by the RAB (Budget Plan), with the principle of cleanliness being part from Faith, the green is not only on reports but also other things such as concern for the surrounding community by involving the community in terms of maintaining cleanliness and preserving the environment such as cleaning trash and grass in the campus area by employing housewives around the campus area, amounting to 15 people, as well as male troops in charge of plant nurseries and replacement of dead plants. The second participant was the Head of Tax and Financial Reporting states that: "Funds relating to the environment at UMM are not only managed by themselves but also in collaboration with the second party, the funds are managed by field II namely administration and general fields and finance. The construction of the GKB 4 Building is a form of building that is planned and programmed to protect the environment because the building is environmentally friendly and in accordance with the topography at UMM. "

The third participant was the Head of the general bureau stating that: "Cooperation in the forestry sector is in the management of campus forests by planting collection trees at UMM. With the launch of the RAB of the university where the implementation was straightforward 
The fourth participant was the Chair of the PSLK stating that the PSLK (Center for Environmental Studies) was a form of environmental activity unit at UMM. Where PSLK has the duty to supervise environmental problems at UMM and business units owned by UMM. Funds used for environmental activities can be from universities or parties II related to tertiary educational activities. Where the funds from the university the process must go through a proposal from PSLK which then requires the approval process, while the funds from the second party come from the lecturer research funds themselves from the Directorate of Higher Education so that besides supporting Tridharma, also helps the existence of environmental conservation. "

From the four participants, it can be concluded that in environmental involvement UMM organizes an environmental unit, namely PSLK (Center for Environmental Studies) where the institution under the auspices of BAU (Administrative and Public Agency) carries out activities to conserve the environment where one of the activities is in the form of community training, namely SMA / SMK and SMP teachers are related to the learning model in the field of environmental conservation with funding from excellent research conducted by the Research and Technology Department.PSLK as the executor tried to supervise business units from UMM such as Hospitals, Hotels, Polyclinics, TPA and TPS, Sengkaling tourist attractions, and gas stations.With criteria in accordance with predetermined Environmental Impact Assessments.

\subsubsection{Environment Reporting}

One measure of green accounting is environmental reporting, which is related to university performance that can be seen by the public. The researcher tried to explore how UMM's reporting was in the environmental field, so from the first participant, the head of the financial bureau, stated that: "the environmental report at UMM was in the form of RAB, all costs incurred for the environment were posted in salary, operational and maintenance costs, performance reports the environment is reported based on the costs incurred for each of the items mentioned above to be one in the financial statements. "

The second participant was the Tax and Financial Reporting Office stating that: "there are no reports relating to environmental performance specifically, all matters relating to environmental funds are united with operational costs, but continuously at meetings of leaders of programs related to the environment overseen by UMM Daily Agency (BPH), and can be in the form of attachments only in financial statements. "

The third participant was the head of the general bureau stating that: "reports relating to environmental performance exist but are not specifically made separately, the report is directly posted to the financial statements in the form of operational costs and salary costs."The fourth participant was the Chair of PSLK stating that: "there are reports relating to environmental performance, more often delivered verbally so that it has not been well documented. So the reporting has not been continuous conducted by UMM, and there has not been a published environmental performance report yet. "

The conclusion that can be drawn by the four participants is that in general there are no specific and detailed environmental expenditure reports that are reported continuously by UMM, because the nature of the report at the organization / university is no provision for financial reporting, so it is an awareness of each institution in terms of organizing and recording environmental performance reporting. 


\subsubsection{Environment Audit}

The audit at UMM was carried out by a unit of institutions called the Internal Audit Agency (BPI) which was tasked with conducting audits of 1) faculty audits, 2) laboratory audits, 3) audits of business charities or business units and 4) audits of supporting units. Specifically from interviews with participant 1, participant 2, participant 3 and participant 4,3 partispan said there were no audit reports on environmental accounting, while 1 participant, namely the head of PSLK stated that: "the environmental audit report was carried out by UMM business units such as Rumah Sick, hotels, polyclinics, recreation areas Sengkaling always conducts audit reports to the environmental department, which is carried out every 3 months, per semester and per year, where in the activities are always accompanied by PLSK. "

The conclusion that can be drawn from this is that UMM has implemented an environmental audit report but in UMM business units not within the faculties, laboratories or support units. In principle, the environmental performance audit is intended for matters that are directly related to the surrounding community.

\subsubsection{Al-Adl}

Activities in an organization require to be fair especially in relation to the rights of others, the rights of the social environment and the rights of the universe. In its activities UMM has applied fair principles such as information dug up at the first participant namely the head of the financial bureau stating that: "UMM holds the human principle as caliph so humans must protect human rights, the environment and nature, related to the concept of green, it is expected that the civitas academics do not just look at the report but also look at all aspects especially in the environment. "The second participant, the Head of Tax and Financial Reporting states that: involvement of the surrounding community such as the recruitment of housewives who do not have a job helps their income so that UMM automatically pays attention to the surrounding social environment. "

The third participant, the head of the general bureau, stated that: "UMM always builds and maintains buildings based on BUPR ministry regulations in terms of buildings and the environment as much as possible by looking at aspects of comfort and energy-saving factors, so in this case the rights of the universe can be created properly. "

The fourth participant was the Chair of the PSLK stating that: "UMM in terms of the environment with the principle of natural balance, especially related to public interests, for example, it has to do with water balance, UMM makes a lake, and in each of its activities UMM always holds the principle of fairness in relation to the rights of others, social environment and the universe. "

The conclusions of the four participants stated that the fair principle proposed by UMM was based on the philosophy of "humans as caliphs" so that humans played an important role in the principle of justice in their environment. Principle of placing the rights of others, the rights of the social environment and the rights of the universe are reflected in the activities of the academic community at UMM.

\subsubsection{Al-Ihsan}

Al-Ihsan is a good deed, without any specific obligation to carry out these rights where if the business is based on Ihsan elements or a process of good intentions, attitudes and behaviors, good transactions, it is expected to provide benefits to stakeholders. The reputation of higher education is related to the Ihsan element, which is related to its social responsibility to the academic community in particular and society in general. So the researchers tried to 
uncover the implementation of the Ihsan element by conducting an interview to the first participant, namely: the head of the financial bureau who stated that: "UMM in the eyes of the community and the academic community are institutions that care about the surrounding environment, namely by distributing parcels to disadvantaged communities around the campus in accordance the basis of Surat Al-Maun, where UMM issued non-academic funds of 300 million every Idul Fitri. "

The second participant, the Head of Tax and Financial Reporting stated that: "The nickname of the paradise of the world was pinned to UMM when officials of the service and friends who visited UMM, by contributing to create patterns that support the environment such as providing vehicle parking in certain areas so as not to cause air pollution. and sound in the campus environment. "

The third participant was the head of the general bureau stating that: "UMM's involvement in the application of renewable energy resources such as micro hydro and solar cells shows that this agency is socially responsible in the eyes of the community because it can provide benefits to the academic community in particular and the community at large.

The fourth participant was the Chair of PSLK stating that: "In connection with the reputation of the university, for campus business units there is a separate study and reporting environment, where each campus business unit is responsible to the relevant environmental services. One of UMM's concern for the environment is to help make PLTMH (Micro Hydro Electric Power Center) in Sumber Maron and Bonpring areas. The implementation of USR was also carried out by UMM by participating in environmental meetings and giving various suggestions relating to the surrounding environment that the benefits can be felt by stakeholders. "

The conclusion of the four participants was that the principle of Al-Ihsan was broadly applied at UMM with the Islamic model of supremacy. UMM strives to contribute to the environment through activities that benefit the community such as the development of renewable energy namely PLTMH which supports saving resources by producing $20 \%$ electricity, which means it can reduce the use of costs. "

\subsubsection{Maslaha}

All forms of higher education activities should provide benefits to the welfare of the surrounding environment both internal and external. Like higher education activities that benefit the community are higher education tridharma activities that support the environment such as counseling activities in the form of community service implemented in accordance with the field of study of each lecturer. There is an institution that specifically handles the environment, namely PSLK, where the institution is a liaison between the university and the community. The researcher conducted an interview with the first participant in relation to the problem, namely with the head of the financial bureau who stated that "environmental management on campus in the form of maintenance and maintenance of parks and infrastructure facilities involves the community with the aim of helping small communities to earn income such as ST 12 troops consisting of mothers household, and also involved troops consisting of men who were also recruited from the community around the campus."

The second participant, the Head of Tax and Financial Reporting stated that "UMM always tries to benefit all elements, both the academic community and the community in general". The third participant was the head of the general bureau stating that: "All maintenance, maintenance and renovation functions are a measure of comfort in the campus environment, so that if these three things are processed properly it will save the operating budget." 
The fourth participant was the Chair of the PSLK stating that: "One form of environmental protection and development is to keep the river free of garbage, prepare water by making lakes, so that the availability of clean water is guaranteed."

The conclusion that can be drawn from all participants is that all forms of social responsibility carried out by UMM have benefited the universe and the surrounding environment, so that it can help the welfare of society. Likewise in the fields of education, health, and empowerment of the marginalized. In education, for example, in community service activities, the health sector is the establishment of polyclinics in campus areas and hospitals whose benefits can be felt directly by the community, as well as other business units such as hotels, gas stations and recreational centers.

\subsubsection{Tafwid}

The role of tertiary institutions in implementing USR in activities related to natural and human resource management always upholds the principle of the mandate and always avoids improper conduct in its activities. UMM also paid attention to the needs of stakeholders, the natural environment and related to social welfare in general. The researcher delved into the question with the first participant, the head of the financial bureau, stating that: "the allocation of funds from the RAB allocated to the environment of 200 million is a form of USR within the university, the funds are allocated according to their respective functions, there is no distortion and there is always reporting. "

The second participant was the Head of Tax and Financial Reporting states that: "UMM social care to the community for example in addition to ST 12, UMM also cooperates with the village government in controlling the boarding environment of students involving RT and RW to control public order, this is directly managed by Warek III, the police and hansip are also involved in this matter. "

The third participant was the head of the public bureau stating that: "activities that support the environment such as maintenance, maintenance and renovation which have different tasks carry out their functions properly at UMM, under the auspices of the public bureau if related to facilities and infrastructure, it will try to maintain all the functions in a decent condition, and there is always financial reporting. "

The fourth participant was the Chair of PSLK stating that: "one form of USR implementation activities at UMM is to provide education and training to the surrounding community, as PSLK does, namely by training high school / vocational and junior high school students related to learning methods for environmental conservation. In connection with campus business units such as hospitals, hotels, gas stations, polyclinics, recreation centers, they always try to comply with the environmental conditions that have been set, of course, by building Islamic values and applying them in every environmental activity. "

The conclusion that can be drawn from the four participants mentioned above is that the principle of trust has been implemented by UMM by upholding Islamic values in every environmental activity. Through education and training with the theme of nature conservation, UMM contributed to the implementation of USR so that UMM took part in the activities of the natural environment where this was to stakeholders and social welfare in general.

\subsection{Research Discussion}

UMM organizes university institutional management in a professional manner based on Islamic values reflected in the Islamic maqasid (MS) with a contemporary concept approach namely MS which is "development" and "right" in implementing green accounting properly which is also supported by the statement of the UMM Rector on April 23, 2016 that "UMM 
became one of the various campus reference campuses as an environmentally friendly campus that should be emulated by its programs related to the environment. The movement as an environmentally friendly campus with the jargon of 'UMM Green, Clean and Comfortabel' was launched in 2013. Therefore, all academicians in UMM must commit to contribute significantly to environmental preservation, "said UMM Rector, Fauzan on the sidelines of Commemoration Day. Earth."

The MS approach taken by Jasser Auda (2007) provides the basis for researchers to establish the basis for developing a broader green accounting implementation of the classical maqasid which is an effort to prevent only compared to the contemporary maqasid which is the development and protection of human rights, and this MS is more support and in accordance with the needs and problems experienced by Muslims today. Then if the classical maqasid is more individual, then the contemporary maqasid puts forward the social aspects. In this study, researchers classified MS at the level of general maqasid, namely maqasid aimed at the whole of Islamic law including dzaruriyat and hijiyyat with the added purpose of the new maqasid namely justice and facilitation. Where in terms of the environment the MS dimension includes the protection of human rights (hifdz al-huquq al-Insan) and the embodiment of social solidarity.

So the researchers found the green accounting implementation model by applying contemporary MS based on the results of data collection at UMM. Where is the application of Green accounting in terms of USR, namely:

a. Environmental awareness, the university carries out environmental care activities based on the vision and mission of the university which implements the values of the Islamic Community, this activity supports USR which is better and Islamic which is in accordance with the principles of Al-Adl, Al-Ihsan, Maslaha, and Tafwid which became the basis for implementing Islamic CSR. By creating activities that support the conservation of nature and creating renewable energy in the form of micro-hydro electricity and solar cells that greatly helps reduce the burden and the amount of energy used in daily activities.

b. Environmental Involvement, the university is involved in the environmental rescue program by establishing the PSLK (Center for Campus Environmental Studies) institution where PSLK is responsible for assisting business units at UMM where all activities are directly supervised by the environmental department. Where all business units at UMM such as hospitals, polyclinics, hotels, recreational centers and gas stations always pay attention to operational standards in their duties and pay attention to the surrounding environment.

c. Environmental Reporting, UMM carries out environmental performance assessment, where the reporting is integrated into the financial report and posted on operational costs and salary costs, and if the report is not as UMM business units, the reporting is based on the activity agenda whereas if it is as a business unit reporting every 3 months, per semester and per year to the environmental service. UMM has not made a published environmental performance report. The environmental performance report at UMM is only as an attachment but it is still being monitored by the university's external party, the Muhammadiyah BPH (Daily Executing Agency).

d. Environmental auditing, UMM has an internal agency that oversees the BPI (Internal Supervisory Agency) which is tasked with conducting audits of faculty activities, business charity activities / business units, laboratory activities, and supporting unit activities. In 
connection with the environmental audit, at the UMM there was an audit of a charity business / business unit which included: Hospitals, polyclinics, hotels, recreational centers and gas stations, where direct audits were conducted by the environmental department.

The implementation of Islamic CSR principles at the university has been done well by UMM, where the university holds firm Islamic values, which is firmly upholding the principle of the proselytizing mission of the Islamic State of Mungkar, which since the Dutch era in 1914, which was legally strengthened by a ministerial decree. Kemuhamadiyahan is engaged in religious, social and educational fields. UMM is an organization that is engaged in education. All activities in the academic community always uphold Islamic values, namely the good deeds of humanity that are reflected in the activities of the lecturers. , community service coupled with al-Islam kemuhamadiyahan. The model produced in this study is :

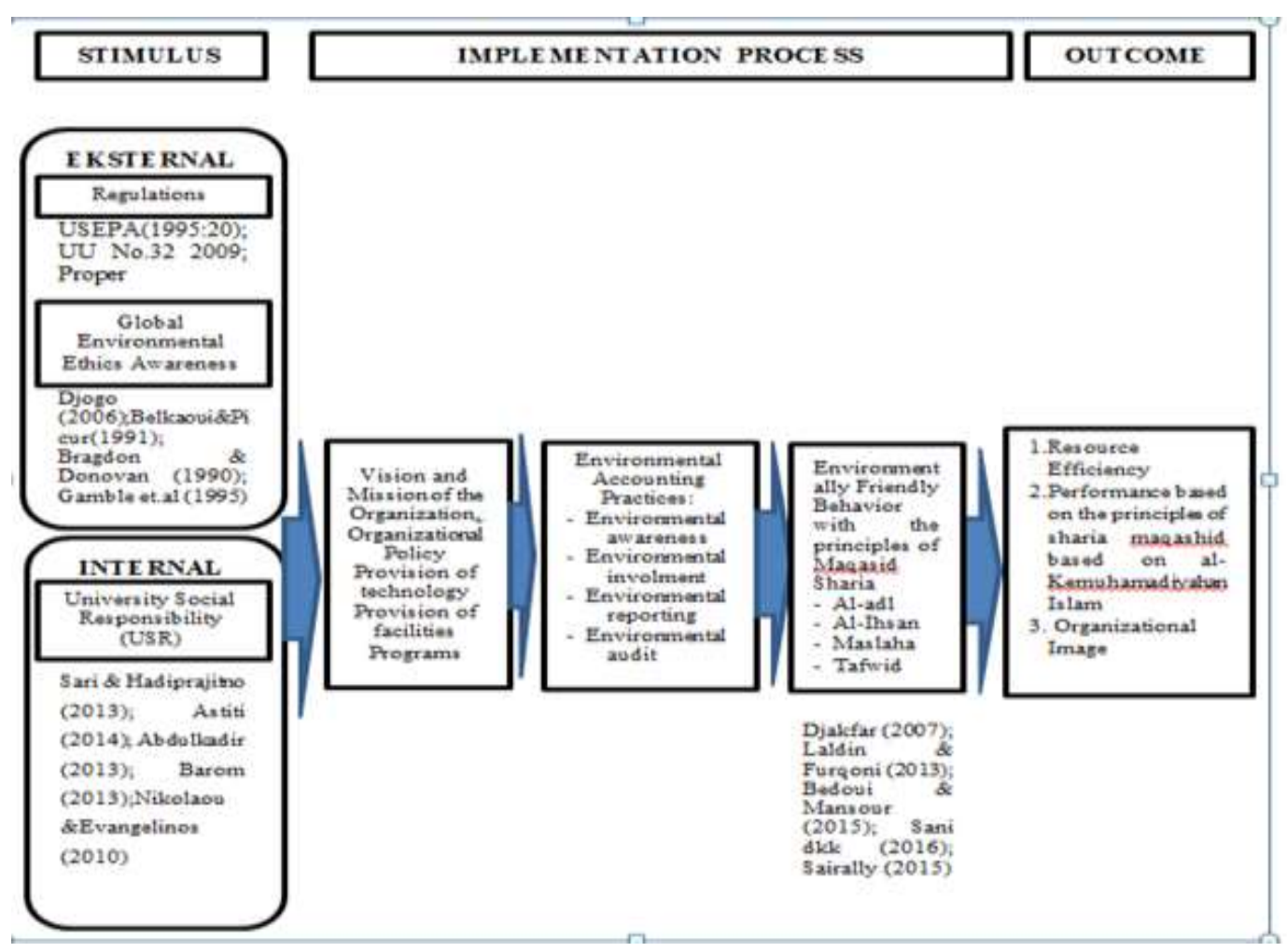

Figure 1: Green Accounting Implementation Model with contemporary Maqasid Sharia approach

\section{Acknowledgement}

I would like to express my deep gratitude to Professor Muslich Anshori and Professor Basuki, my research supervisors, for their patient guidance, enthusiastic encouragement and 
useful critiques of this research work. I would also like to thank for their advice and assistance in keeping my progress on schedule.

Finally, I wish to thank my husband, my children and my parents for their support and encouragement throughout my paper.

\section{References}

Abdulkadir, A. B. 2013. "An expository study of the islamic approach in the jurisprudence of right to healthful environment". IIUM Law Journal, Vol. 21, No. 1, hlm.

Akram Laldin, M., dan H. Furqani. 2013. "Developing islamic finance in the framework of maqasid al-shari'ah: Understanding the ends (maqasid) and the means (wasa'il)". International Journal of Islamic and Middle Eastern Finance and Management, Vol. 6, No. 4, hlm 278-289.

Astiti, W. 2014. "Implementasi green accounting berbasis university social responsibility (usr) di universitas negeri yogyakarta". Nominal, Barometer Riset Akuntansi dan Manajemen, Vol. 3, No. 2, hlm.

Auda, J. 2008. Maqasid al-shariah as philosophy of islamic law: A systems approach: International Institute of Islamic Thought (IIIT).

Barom, M. N. 2013. "Conceptualizing a strategic framework of social responsibility in islamic economics". International Journal of Economics, Management and Accounting, Vol. 21, No. 1, hlm.

Bedoui, H. E., dan W. Mansour. 2015. "Performance and maqasid al-shari'ah's pentagonshaped ethical measurement". Science and engineering ethics, Vol. 21, No. 3, hlm 555-576.

Belkaoui, A. R., dan R. D. Picur. 1991. "Cultural determinism and the perception of accounting concepts". International Journal of Accounting, Vol. 26, No. 2, hlm 118130.

Bragdon, P., dan B. Donovan. 1990. "Voters' concerns are turning the political agenda green". Congressional Quarterly Weekly Report, Vol. 48, No., hlm 186-187.

Djogo, T. 2006. "Akuntansi lingkungan". www. beritabumi h-2. com, Vol., No., hlm.

Gamble, G. O., K. Hsu, D. Kite, dan R. R. Radtke. 1995. "Environmental disclosures in annual reports and 10ks: An examination". Accounting Horizons, Vol. 9, No. 3, hlm 34.

Jahamani, Y. F. 2003. "Green accounting in developing countries: The case of uae and jordan". Managerial Finance, Vol. 29, No. 8, hlm 37-45.

Mohamad, M. H. S., M. A. Ali, dan R. A. M. Sharif. 2016. "Determinants of maqāșid al-sharī 'ah-based performance measurement practices: The case of malaysian islamic banks". International Journal of Economics, Management and Accounting, Vol. 24, No. 1, hlm 49-81.

Nikolaou, I. E., dan K. I. Evangelinos. 2010. "Classifying current social responsibility accounting methods for assisting a dialogue between business and society". Social Responsibility Journal, Vol. 6, No. 4, hlm 562-580.

Rodin, D. 2017. "Alquran dan konservasi lingkungan: Telaah ayat-ayat ekologis". Al-Tahrir: journal of Islamic Thought, Vol. 17, No. 2, hlm 391-410.

Sairally, B. S. 2015. "Integrating environmental, social and governance (esg) factors in islamic finance: Towards the realisation of maqasid al-shari'ah". ISRA International Journal of Islamic Finance, Vol. 7, No. 2, hlm 145. 
Sari, M. P., dan P. B. Hadiprajitno. 2013. "Pengawasan impelementasi "green accounting" berbasis university social responsibilities (usr) di universitas negeri semarang serta studi komparasi universitas se-kota semarang". Jurnal Akuntansi dan Auditing, Vol. 9, No. 2, hlm 169-198.

Wahyuddin, W. 2016. "Islamic corporate sosial responsibility (icsr); kajian teoritis". Jurnal Akad, Vol. 1, No. 1, hlm. 